Article

\title{
Aromatic Thioacetal-Bridged ROS-Responsive Nanoparticles as Novel Gene Delivery Vehicles
}

\author{
Guo-Qing Lin, Wen-Jing Yi *, Qiang Liu, Xue-Jun Yang and Zhi-Gang Zhao * \\ College of Chemistry and Environmental Protection Engineering, Southwest Minzu University, Chengdu 610041, \\ China; lgq1012966356@163.com (G.-Q.L.); lqchem@163.com (Q.L.); yangxuejun@swun.edu.cn (X.-J.Y.) \\ * Correspondence: ywjchem@163.com (W.-J.Y.); zzg63129@163.com (Z.-G.Z.); \\ Tel.: +86-8552-2315 (W.-J.Y. \& Z.-G.Z.)
}

Received: 16 July 2018; Accepted: 11 August 2018; Published: 17 August 2018

\begin{abstract}
In this report, a series of polycations are designed and synthesized by conjugating reactive oxygen species (ROS)-responsive thioacetal-linkers to low molecular weight (LMW) polyethylenimine (PEI) via ring-opening polymerization. Their structure-activity relationships (SARs) as gene delivery vectors are systematically studied. Although the MWs of the target polymers are only $\sim 9 \mathrm{KDa}$, they show good DNA binding ability. The formed polyplexes, which are stable toward serum but decomposed under ROS-conditions, have appropriate sizes $(180 \sim 300 \mathrm{~nm})$ and positive zeta-potentials $(+35 \sim 50 \mathrm{mV})$. In vitro experiments reveal that these materials have low cytotoxicity, and higher transfection efficiency (TE) than controls. Furthermore, the title polymers exhibit excellent serum tolerance. With the present of $10 \%$ serum, the TE of the polymers even increases up to 10 times higher than $25 \mathrm{KDa}$ PEI and 9 times higher than Lipofectamine 2000. The SAR studies also reveal that electron-withdrawing groups on the aromatic ring in 4a may benefit to balance between the DNA condensation and release for efficient gene transfection.
\end{abstract}

Keywords: reactive oxygen species (ROS); stimuli responsive; gene delivery; cationic polymer; non-viral vectors

\section{Introduction}

Gene therapy is considered to be one of the most promising approaches to treating various human genetic and acquired diseases, such as cancers, aging, diabetes, and cardiovascular diseases [1]. Safe and effective gene delivery vectors are a prerequisite for successful gene therapy [2,3]. Due to the high transfection efficiency (TE), viral carriers are a commonly used method of gene delivery. However, their immunogenicity, toxicity, limited DNA packaging capacity, and difficulty in large-scale production have impeded their development and clinic applications [4,5]. In attempt to overcome these barriers, a broad range of versatile and efficient non-viral gene vectors have been developed. Cationic polymers, as one class of non-viral gene vectors, have acquired increasing attention due to their easy preparation and modification in recent years [6-8].

Gene transfection with cationic polymers needs to overcome multiple delivery barriers, including the formation of polymers/DNA complexes (polyplexes) and their initial binding to the cell surface, endocytosis, endosomal escape, nuclear entry, and final expression [9-11]. "Golden standard" 25 KDa PEI is the most widely studied polymeric carrier, both in vitro and in vivo [12]. Unfortunately, high molecular weight (HMW) PEI remains cationic under physiological conditions and is not biodegradable, resulting in its well-known cytotoxicity, the difficult release of genes and low TE under serum conditions [13,14]. Compared to the HMW PEI, the LMW PEI illustrates much lower toxicity, yet almost no transfection activity [15]. Recently, plentiful approaches to obtaining high TE using covalently conjugated and non-conveniently assembled LMW PEI have been investigated [16,17]. 
One of the feasible approaches is to cross-link LMW PEI with biodegradable linkers (ester, ketal and disulfide etc.) $[13,18,19]$ to form "smart" polymers that can eventually degrade into small molecules and simultaneously release complexed nucleic acids in the internal or external stimuli ( $\mathrm{pH}$, redox, temperature, light, and magnetic field etc.) [20-23].

Such endogenous stimuli that are drawing keen attention recently are reactive oxygen species (ROS), which include hydrogen peroxides $\left(\mathrm{H}_{2} \mathrm{O}_{2}\right)$, hydroxyl radicals $(\cdot \mathrm{OH})$, peroxynitrites $\left(\mathrm{ONOO}^{-}\right)$ and superoxides $\left(\mathrm{O}_{2}^{-}\right)$[24-27]. Commonly, $\mathrm{ROS}$ are generated from mitochondrial electron transport as a byproduct, and they are used in cell signaling of normal cells or cause oxidative stress from overproduction [28]. On the other hand, a number of evidences reveal that chronically increased levels of ROS are closely associated with various pathological disorders including cancer, atherosclerosis, diabetes, infections, inflammatory diseases, where ROS levels can be 10- to 100-times higher than those of the normal levels [29-31]. Therefore, ROS can be considered as a target or an indicator for selectively delivering cargo molecules to diseased sites by targeting oxidative microenvironment at different levels. Some materials that can undergo phase transition or hydrolyze under oxidative conditions therefore have been developed to construct ROS-sensitive carriers. Alternatively, some oxidation-labile groups (thioether, thioketal [25,26,32], selenium-containing groups, oligoproline peptide and boronic acid esters etc.) are incorporated into polymers as ROS-responsive groups [33-36]. It was hypothesized that the ROS-responsive nanocarriers could facilitate the intracellular gene release and transfection expression inspired by the high level of intracellular ROS.

Based on the above issues, the aim of this study was to develop novel biodegradable polymeric nanocarriers based on LWM PEI and thioacetal-linker units, exploiting the high level of ROS in cancer cells (as shown in Scheme 1). In addition, rigid aromatic structure containing polymers showed increased TE was recently reported by our group [37-39]. The aromatic rings may help to improve the DNA condensation ability of cationic polymers. Besides, we also found diepoxide ring-opening polymerization is a practical synthetic method toward polymeric vectors with high biological compatibility by the newly formed hydroxyls and oxygen atoms similar to PEG structure [38-42]. Hence, we prepared this series of polycations through the epoxide ring-opening polymerization from bis-epoxides with various aromatic thioacetal groups. Then, their gene delivery properties (such as DNA condensation, cytocompatibility, in vitro TE) and structure-property correlations were systematically investigated.

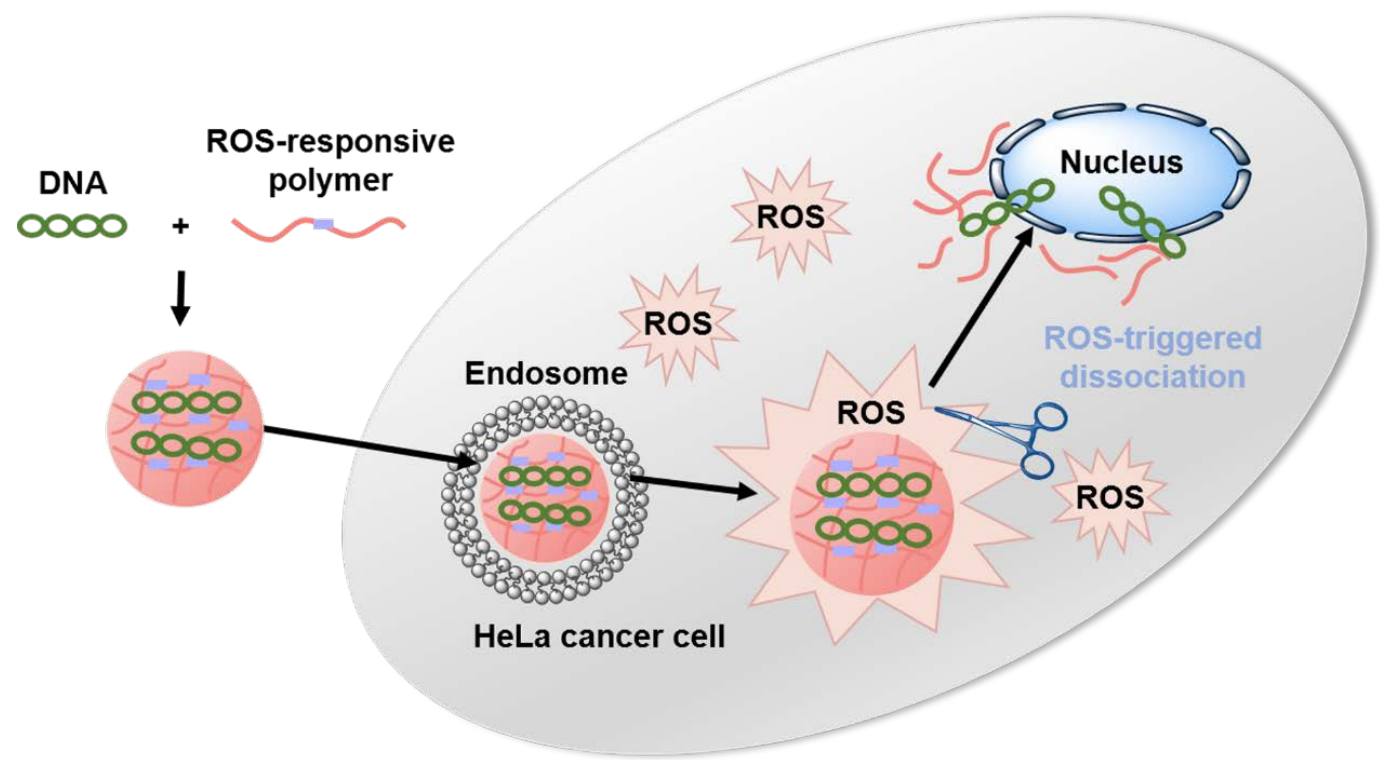

Scheme 1. Illustration of intracellular delivery of plasmid DNA to the nucleus of HeLa cancer cell using ROS-responsive polymer based LWM PEI and thioacetal-linker units. 


\section{Results and Discussion}

\subsection{Polymer Synthesis and Characterization}

The preparation route for the target polymers is shown in Scheme 2. Various aromatic aldehydes 1 reacted with 2-mercaptoethanol to give compound 2 in the presence of catalyst $\mathrm{NiCl}_{2} \cdot 6 \mathrm{H}_{2} \mathrm{O}$. Subsequently, diglycidyl ether $\mathbf{3}$ was prepared by the reaction of $\mathbf{2}$ with epichlorohydrin in the presence of $\mathrm{NaOH}$ and water with $\mathrm{Bu}_{4} \mathrm{NBr}$ as a phase transfer catalyst. The ring-opening polymerization was simply processed between equal molar amounts of diglycidyl ethers cross-linker 3 and PEI 600 Da in refluxed ethanol. The crude product was recrystallized for 3 times with anhydrous DCM and methanol to ensure their polydispersity. The obtained polymers showed significant water solubility, which was required for the subsequent studies. Moreover, four diglycidyl ether bridges with varied electron-effects (electron-donating and electron-withdrawing substituents) were introduced for helping us to elucidate the structure-activity relationships (SARs). These new compounds were characterized by ${ }^{1} \mathrm{H}-\mathrm{NMR}(400 \mathrm{MHz})$ using $\mathrm{D}_{2} \mathrm{O}$ as a solvent. Although the molar ratio of the substrates (bridge and PEI 600) for polymerization was 1:1, the integral ratio of the proton signals from the bridge $(18 \mathrm{H}$ each) and PEI (56H each) revealed that the units of the bridge were more than the latter, indicating the formation of a reticular but not linear structure (Supplementary Materials). The molecular weights of target polymers 4 were measured by GPC, and results in Table 1 showed that the $\mathrm{M}_{\mathrm{w}} \mathrm{s}$ were found to be in the range of 7-10 KDa and the PDIs (polymer dispersity index) were relatively high around 1.3 2. Because it is well-known that the higher molecular weight of polymers always comes with higher cytotoxicity [38], we hope our materials would have lower toxicity while maintaining high TE.

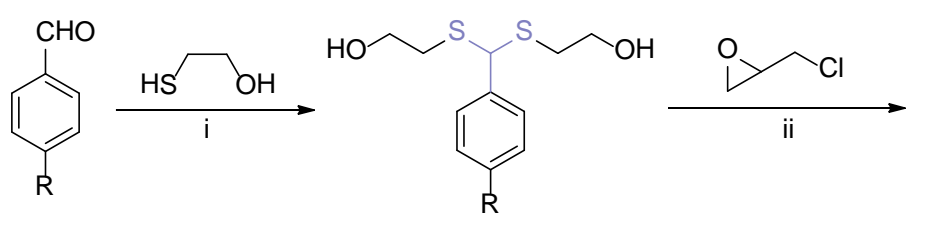

1
2<smiles>[R]c1ccc(C(SCCOCC2CO2)SCCOCC2CO2)cc1</smiles>

3

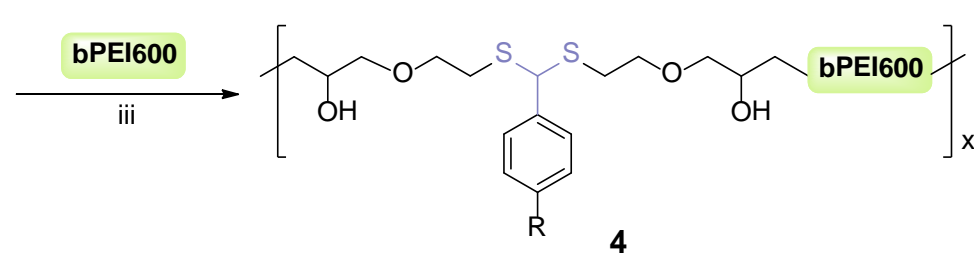<smiles>CC(C)(C)CCNCCN(CCN)CCC(C)(C)C</smiles>

$$
\mathbf{a}: \mathbf{R}=\mathrm{OCH}_{3} ; \quad \mathbf{b}: \mathbf{R}=\mathrm{H} ; \quad \mathbf{c}: \mathbf{R}=\mathrm{F} ; \quad \mathbf{d}: \mathbf{R}=\mathrm{CF}_{3}
$$

Scheme 2. Synthetic route of the target polymers. (i) $\mathrm{NiCl}_{2} \cdot 6 \mathrm{H}_{2} \mathrm{O}$, rt. (ii) epichlorohydrin, $\mathrm{Bu}_{4} \mathrm{NBr}$, $\mathrm{NaOH}, \mathrm{NaOH}, \mathrm{H}_{2} \mathrm{O}, 35^{\circ} \mathrm{C}$. (iii) $\mathrm{EtOH}$, reflux.

Table 1. Molecular weights and polydispersities of the target polymers.

\begin{tabular}{ccc}
\hline Polymers & $\mathbf{M}_{\mathbf{w}} \mathbf{( D a )}$ & PDI \\
\hline $\mathbf{4 a}$ & 9871 & 1.85 \\
$\mathbf{4 b}$ & 10,916 & 1.97 \\
$\mathbf{4 c}$ & 7123 & 1.70 \\
$\mathbf{4 d}$ & 8209 & 1.40 \\
\hline
\end{tabular}




\subsection{Polymer Responds to Reactive Oxygen Species}

With the polymer 4 in hand, we investigated its response to ROS under simulated conditions. In a typical experiment, polymer 4 was dissolved in $\mathrm{D}_{2} \mathrm{O}$ containing $100 \mathrm{mM} \mathrm{H}_{2} \mathrm{O}_{2}$ to trigger its degradation. When the polymer was incubated at $37^{\circ} \mathrm{C}$ for different times, the disappearance of thioketal linkage peak $(\delta \approx 5.20 \mathrm{ppm})$ was monitored by ${ }^{1} \mathrm{H}-\mathrm{NMR}$ spectroscopy (Figure S2, Supplementary Materials). The ${ }^{1} \mathrm{H}-\mathrm{NMR}$ spectrum confirmed that the thioketal linkages were efficiently cleaved by ROS, generating substituted benzaldehyde $(\delta \approx 8.25 \mathrm{ppm})$ as a byproduct during the cleavage process.

\subsection{Interaction with Plasmid DNA and Characterization of Polyplexes}

Condensation of negatively charged DNA into nano-sized particles is a prerequisite of great importance for well-designed polymeric vectors. The formation of a polyplex can reduce the electrostatic repulsion between DNA and the cell surface, and can protect DNA against enzymatic degradation by nucleases in cytoplasm or serum [43]. Agarose gel electrophoresis was used to evaluate the DNA binding ability between the polymer and DNA at various weight ratios (polymer/DNA, $w / w)$, and results were shown in Figure 1. All 4 materials exhibited good DNA binding capacity, and full DNA retardation could be observed at a relatively low dosage from the $w / w$ ratio of $\sim 0.5$. The structure of aromatic substituent seemed to have little effect on their DNA retardation ability. However, polymers could not efficiently complex with DNA even at a high $w / w$ ratio of 8 after exposed to ROS (Figure S3, Supplementary Materials). This finding implied that polymer 4 was decomposed following incubation with $\mathrm{H}_{2} \mathrm{O}_{2}$.

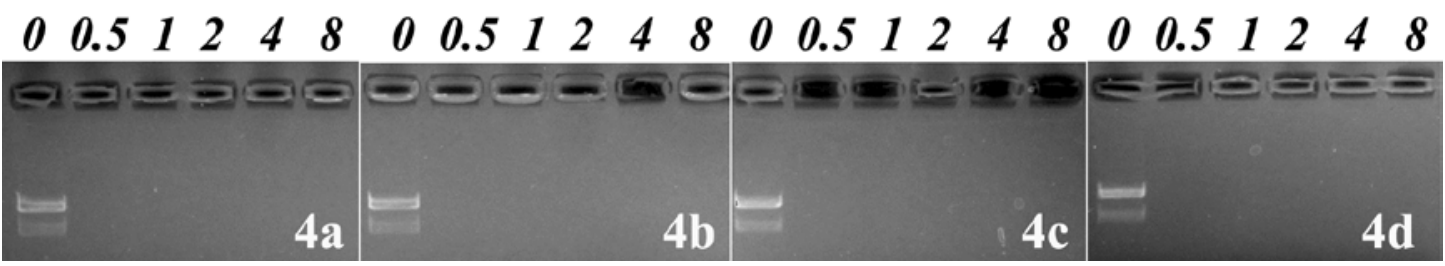

Figure 1. Agarose gel electrophoresis assays of polymer/DNA (pUC19) complexes at different $w / w$ ratios. In each image, the first lane is the DNA control.

Proper particle size and positive surface charge are essential for efficient gene delivery. It was reported that complexes within the size range of 50 to several hundred nanometers would receive easier endocytosis [44]. Dynamic light scattering (DLS) measurements showed that the particle sizes of 4/DNA polyplexes changed dramatically at relatively low $w / w$ ratios $(0.5-1)$, and became constant at $180 \sim 300 \mathrm{~nm}$ with the increase of $w / w$ ratio (Figure 2A). The larger particles formed at the $w / w$ ratio of $0.5-1$ might be attributed to their neutral zeta-potential, which led to the minimized repulsion and resulting aggregation. Meanwhile, we also examined the possible changes of particle sizes of 4a/DNA at a $w / w$ ratio of 2 in the presence of $10 \%$ serum. Results suggested that the particle sizes of polyplexes were still stable at $\sim 250 \mathrm{~nm}$ and seldom altered, indicating that no apparent aggregation occurred (Figure S1, Supplementary Materials). Zeta potential shown in Figure 2B indicated the surface charge rose along with the increase of $w / w$ ratios, and reached about $+35 \sim 50 \mathrm{mV}$ above a $w / w$ ratio of 2 . Interestingly, the polyplexes with electron-donating substitute revealed lower zeta potential than the electron-withdrawing ones, which might be due to the positive charge screening by the electron-rich effect. Generally, the positively charged complexes can interact with the negatively charged cellular membranes, leading to more efficient cellular uptake [40]. 
A

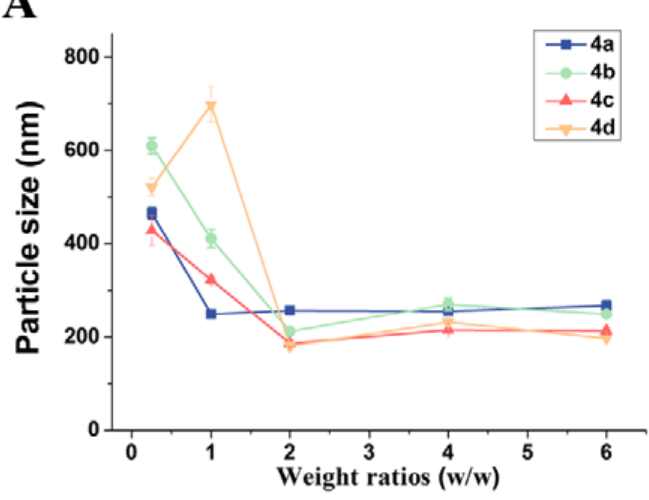

B

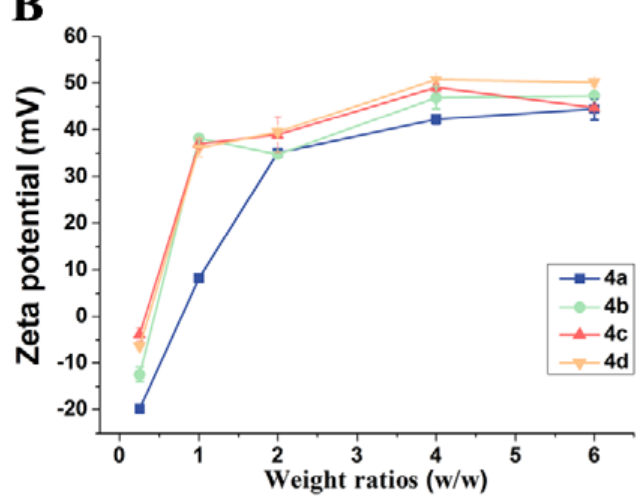

Figure 2. Particle size (A) and zeta-potential (B) of polymer/DNA polyplexes obtained at various $w / w$ ratios by DLS. Data are represented by mean \pm standard deviation (S.D.) $(n=3)$.

\subsection{In Vitro Gene Transfection}

The in vitro TE of the new polyplexes was evaluated in HeLa cells with high ROS levels by using pGL3 plasmid as a luciferase reporter gene. Figure 3A shows the relative TEs at various $w / w$ ratios in a serum-free medium, and Lipofectamine 2000, 25 KDa PEI and PEI 600 were used as controls. All the polymers at $w / w$ ratios of 2 and 4 gave comparable TEs to commercial reagent Lipofectamine 2000. To our delight, polymer 4a gave the highest TE, which was nearly 4.5 times higher TE than Lipofectamine 2000 and 1.5 times higher TE than 25 KDa PEI at a $w / w$ ratio of 2. The electron-withdrawing groups on the aromatic ring seemed to play an important role in the transfection process. We speculate that the lower zeta potentials caused by the electron-rich effect in $4 \mathbf{a}$ might benefit the dissociation of the polyplexes, leading to better release of DNA in the cytosol [40].

In general, the interaction between negatively charged serum proteins and polycationic gene vector would inhibit efficient gene delivery [45]. Previous results in DLS experiment showed good serum tolerance of our new material. The transfection ability of the polymers in the presence of serum was also estimated by the same method. As shown in Figure 3B, it was found that the relative TE was even higher for all synthesized polymers in the presence of $10 \%$ of serum, indicating that these polyplexes were quite stable and were seldom affected by the serum. Especially 4a polyplexes, demonstrated approximately 10 times higher TE than Lipofectamine 2000 and 9 times higher than $25 \mathrm{KDa}$ PEI, respectively. Besides the aromatic group, the hydroxyls formed from ring-opening polymerization would also contribute to the excellent serum tolerance [38,41].
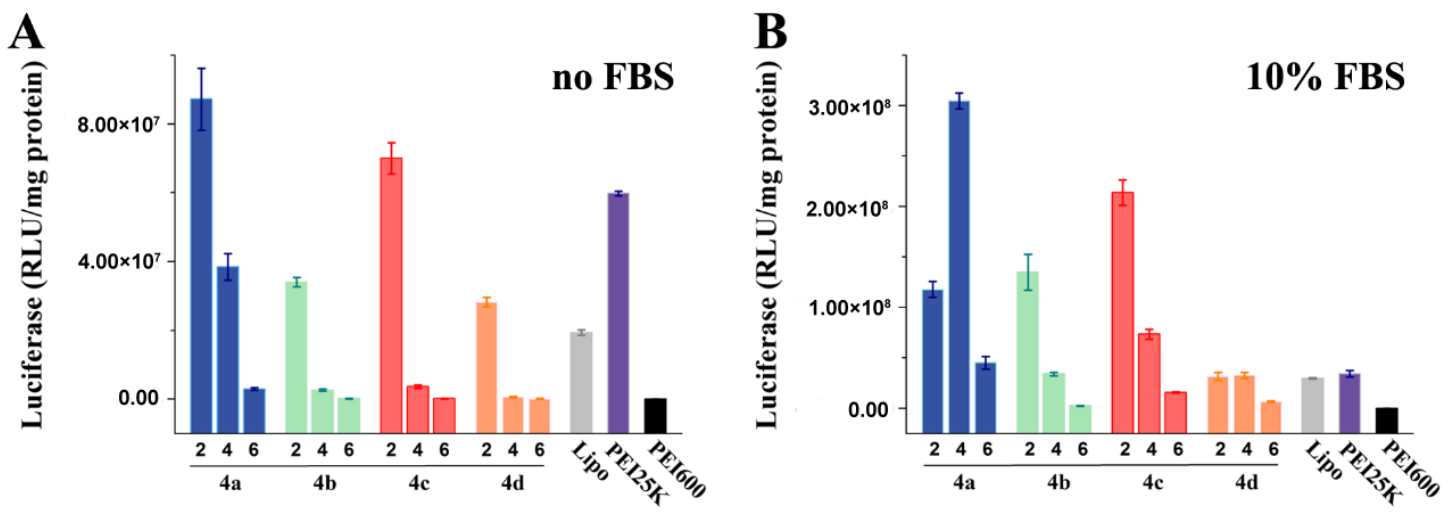

Figure 3. Luciferase gene expression transfected by polyplexes at different weight ratios: 2,4 , and 6 in comparison with Lipofectamine 2000, PEI $600(w / w=6, \mathrm{~N} / \mathrm{P}=28.7)$ and $25 \mathrm{KDa}$ PEI $(w / w=1.4$, $\mathrm{N} / \mathrm{P}=10)$ in human human cervix carcinoma cell lines (HeLa) in the absence of serum (A) and in the presence of $10 \%$ serum $(\mathbf{B})$. Data are represented by mean \pm S.D. $(n=3)$. 
To directly visualize the infected cells expressing green fluorescent protein reporter gene pEGFP-Nl, enhanced green fluorescent protein expression in HeLa cells was observed by an inverted fluorescent microscope. The $w / w$ ratios were used according to the optimal results from luciferase assays, and the images are shown in Figure 4. Similar to the results in luciferase assay, polymer $4 a$ gave the strongest green fluorescence among the four polymers, and the density of expressed GFP was also higher than that involving control PEI $25 \mathrm{KDa}$ and Lipofectamine 2000. Serum seemed to have no negative effect on the transfection mediated by 4 ; however, PEI $25 \mathrm{KDa}$-participated transfection was inhibited by serum on account of high positive charges. All results further demonstrated the good serum tolerance of our new vectors.

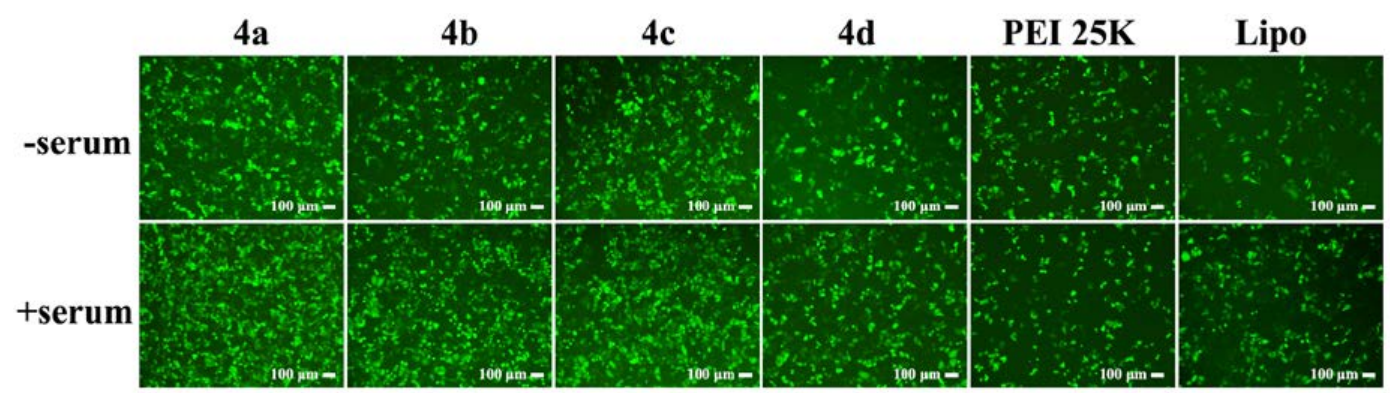

Figure 4. Fluorescence microscope image of pEGFP-transfected HeLa cells at optimal weight ratios in the absence of serum ( 2 for $4 \mathbf{a}-\mathbf{d}$ ) or in the presence of 10\% FBS ( 4 for $4 \mathbf{a}$ and $4 \mathbf{d}, 2$ for $4 \mathbf{b}$ and $4 \mathbf{c}$ ).

\subsection{Cytotoxicity}

Successful gene transfection requires efficient transfection and minimized cytotoxicity. However, most of the polymeric are caught in the dilemma: either high TE associated with severe cytotoxicity, or low TE with better compatibility [26]. These new polycations have molecular weight around $9 \mathrm{KDa}$, and previous experiments exhibited that although their molecular weights are relatively low, they could completely condense DNA even at low $w / w$ ratios ( 0.5). We hope their small molecular weights may result in low toxicity. The cytotoxicities of the polyplexes were studied and compared with PEI 25 KDa and Lipofectamine 2000 in HeLa cells via CCK-8 assays. It should be noted that the $w / w$ ratio for CCK-8 assay was the same as that used in the transfection experiment. As shown in Figure 5, the cell viabilities of the studied materials were higher than those of $25 \mathrm{KDa}$ PEI and Lipofectamine 2000 even at high $w / w$ ratios in most cases, suggesting that these polymers had better biocompatibility. Comparing to the structure of bPEI, we believe that the lower cytotoxicity may be attributed to the newly formed hydroxyl groups and biodegradable thioacetal, which can benefit the biocompatibility of the polymeric materials used for gene delivery. It was also proved that the ring-opening polymerization from bis-epoxides is an effective synthetic approach toward materials with low cytotoxicity.

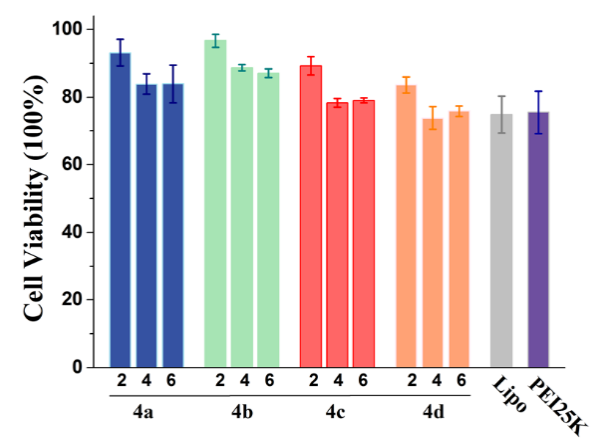

Figure 5. Cytotoxicity of polyplexes at different $w / w$ ratios toward HeLa cells. Lipofectamine 2000 and PEI 25 KDa were used as controls $(w / w=1.4, \mathrm{~N} / \mathrm{P}=10)$. Data are represented by mean \pm S.D. $(n=3)$. 


\section{Experimental Section}

\subsection{Materials and Methods}

Anhydrous $\mathrm{MeOH}, \mathrm{EtOH}$ and dichloromethane (DCM) were distilled immediately before use after drying and purifying by using standard methods. 2,2'-((4-methoxyphenyl)methylene)bis(sulfanediyl)) diethanol (2a), 2,2'-((phenylmethylene)bis(sulfanediyl))diethanol (2b) and 2,2'-((4-fluorophenyl) methylene)bis(sulfanediyl))diethanol (2c) were prepared according to the literature [46]. 0.6 KDa and 25 KDa branched polyethylenimine (PEI) (99\%, Sigma-Aldrich, St. Louis, MO, USA), Dulbecco's Modified Eagle's Medium (DMEM) and fetal bovine serum (FBS) (Invitrogen Corp., Carlsbad, CA, USA), MicroBCA protein assay kit (Pierce, Appleton, WI, USA), Luciferase assay kit (Promega, Madison, WI, USA), Endotoxin free plasmid purification kit (TIANGEN, Beijing, China) were used as received. Luciferase (pGL-3) and green fluorescent protein (pEGFP-N1) plasmid DNA were purchased from Promega and Clontech. The supercoiled plasmid DNA (pUC-19) used in agarose-gel assay was purchased from Takara (Dalian, China). HeLa cells (human cervix carcinoma cell lines) were purchased from Shanghai Institute of Biochemistry and Cell Biology, Chinese Academy of Sciences. All the other chemicals reagents and solvents of analytical grade, if not specified, were used as received from commercial sources without further purification.

The ${ }^{1} \mathrm{H}-\mathrm{NMR}$ spectra were recorded at $400 \mathrm{MHz}$ and ${ }^{13} \mathrm{C}$ spectra at $100 \mathrm{MHz}$ on a Varian INOVA-400 spectrometer (Varian, Palo Alto, CA, USA). The high-resolution mass spectrometry (HRMS) experiments were performed using a Finnigan LCQDECA (Thermo Scientific, Waltham, MA, USA) and a Bruker Daltonics BioTOF mass spectrometer (Bruker Daltonics Inc., Billerica, MA, USA). The $\mathrm{M}_{\mathrm{w}}$ and polydispersity index (PDI) of the target polymers were determined by gel permeation chromatography (GPC) system, which consisted of Shodex columns OHPAK KB-803, Waters 515 pump and Waters 2410 Refractive Index Detector. $0.5 \mathrm{~mol} \cdot \mathrm{L}^{-1} \mathrm{HAc} / \mathrm{NaAc}$ buffer was passed through a filter and used as the mobile phase, at a flow rate of $0.5 \mathrm{~mL} \cdot \mathrm{min}^{-1} . \mathrm{M}_{\mathrm{W}} \mathrm{s}$ were calculated against PEG standards of $\mathrm{M}_{n}$ ranging from 900 to 80,000 .

\subsection{Synthesis of Title Polymers}

3.2.1. Preparation of 2,2'-((4-(Trifluoromethyl)phenyl)methylene)bis(sulfanediyl))diethanol (Compound 2d)

4-(Trifluoromethyl)benzaldehyde (1d, $20 \mathrm{mmol}, 3.48 \mathrm{~g}$ ) was mixed with 2-mercaptoethanol (40 mmol, $3.12 \mathrm{~g})$. After addition of the catalyst $\mathrm{NiCl}_{2} \cdot 6 \mathrm{H}_{2} \mathrm{O}(0.1 \mathrm{mmol}, 23.8 \mathrm{mg})$, the solution was stirred at room temperature for $1 \mathrm{~h}$, and then $10 \mathrm{~mL}$ DCM was added to separate out the catalyst by filtering off. The solvent was concentrated to afford a white solid, which was purified by column chromatography on a silica gel (DCM:MeOH $=40: 1, v / v)$ to give compound $\mathbf{2 d}$ as a white solid. Yield: 77.6\%. ${ }^{1} \mathrm{H}-\mathrm{NMR}\left(400 \mathrm{MHz}, \mathrm{CDCl}_{3}\right) \delta(\mathrm{ppm}) 7.69-7.48(\mathrm{~m}, 4 \mathrm{H}, \mathrm{PhH}), 5.18$ (s, 1H, -SCHS-), 3.78 (t, $\left.J=5.8 \mathrm{~Hz}, 4 \mathrm{H},-\mathrm{CH}_{2} \mathrm{OH}\right), 2.96-2.66\left(\mathrm{~m}, 4 \mathrm{H},-\mathrm{CH}_{2} \mathrm{CH}_{2} \mathrm{OH}\right) .{ }^{13} \mathrm{C}-\mathrm{NMR}\left(100 \mathrm{MHz}, \mathrm{CDCl}_{3}\right) \delta(\mathrm{ppm}) 144.16$, 128.10, 125.77, 125.73, 125.70, 125.66, 61.57, 52.57, 35.32. HRMS (ESI): $m / z$ calcd. for $\mathrm{C}_{12} \mathrm{H}_{15} \mathrm{~F}_{3} \mathrm{O}_{2} \mathrm{~S}_{2}$ $(\mathrm{M}+)$ 312.0466; found $=335.0358\left([\mathrm{M}+\mathrm{Na}]^{+}, 100\right)$.

\subsubsection{Preparation of Diglycidyl Ether Linkers 3}

Compounds 3 were obtained using the method previously reported $[37,40]$. Briefly, compound $2(0.02 \mathrm{~mol})$, epichlorohydrin $(4.67 \mathrm{~mL}, 0.06 \mathrm{~mol}), \mathrm{NaOH}(2.4 \mathrm{~g}, 0.06 \mathrm{~mol})$, tetrabutylammonium chloride $(0.3224 \mathrm{~g}, 0.001 \mathrm{~mol})$ and pure water $(1 \mathrm{~mL}, 0.056 \mathrm{~mol})$ were mixed at room temperature and stirred at $35{ }^{\circ} \mathrm{C}$ overnight. The solid residue was separated out by filtering off and washed with DCM. The combined solvent was concentrated, and the residue was purified by a silica gel column chromatography to give the compound 3. Analytical data for new compounds $3 \mathbf{a}-\mathbf{d}$ were:

3a: white solid, yield: 31.2\%. Eluent: PE/EA = 3:1 $(v / v) .{ }^{1} \mathrm{H}-\mathrm{NMR}\left(400 \mathrm{MHz}, \mathrm{CDCl}_{3}\right): \delta(\mathrm{ppm})$ 7.39-6.84 (m, 4H, PhH), 5.12 (s, 1H, -SCHS-), 3.81-3.78 (m, 3H, - $\left.\mathrm{OCH}_{3}\right), 3.76-3.33\left(\mathrm{~m}, 8 \mathrm{H},-\mathrm{CH}_{2} \mathrm{OCH}_{2}-\right.$ ), 
$3.13(\mathrm{~m}, 2 \mathrm{H}$, ring $\mathrm{CH}), 2.85-2.77\left(\mathrm{~m}, 4 \mathrm{H},-\mathrm{SCH}_{2}\right), 2.73-2.59\left(\mathrm{~m}, 4 \mathrm{H}\right.$, ring $\left.\mathrm{CH}_{2}\right) .{ }^{13} \mathrm{C}-\mathrm{NMR}(100 \mathrm{MHz}$, $\mathrm{CDCl}_{3}$ ): $\delta$ (ppm) 159.18, 132.14, 128.92, 113.84, 71.50, 70.96, 55.25, 53.26, 50.72, 44.11, 31.73. HRMS (ESI): $m / z$ calcd. for $\mathrm{C}_{18} \mathrm{H}_{26} \mathrm{O}_{5} \mathrm{~S}_{2}(\mathrm{M}+)$ 386.1222; found $=409.1117\left([\mathrm{M}+\mathrm{Na}]^{+}, 100\right)$.

3b: white solid, yield: 33.6\%. Eluent: PE/EA = 3:1 (v/v). ${ }^{1} \mathrm{H}-\mathrm{NMR}\left(400 \mathrm{MHz}, \mathrm{CDCl}_{3}\right): \delta(\mathrm{ppm})$ 7.45-7.25 (m, 4H, $\mathrm{PhH}), 5.12$ (s, 1H, -SCHS-), 3.76-3.35 (m, 8H, - $\left.\mathrm{CH}_{2} \mathrm{OCH}_{2}-\right)$, 3.14-3.12 (m, 2H, ring $\mathrm{CH}), 2.85-2.78\left(\mathrm{~m}, 4 \mathrm{H},-\mathrm{SCH}_{2}\right), 2.75-2.60\left(\mathrm{~m}, 4 \mathrm{H}\right.$, ring $\left.\mathrm{CH}_{2}\right) .{ }^{13} \mathrm{C}-\mathrm{NMR}\left(100 \mathrm{MHz}, \mathrm{CDCl}_{3}\right): \delta(\mathrm{ppm})$ 140.20, 128.55, 127.97, 127.73, 71.52, 70.96, 70.93, 53.84, 50.74, 44.15, 31.74. HRMS (ESI): $m / z$ calcd. for $\mathrm{C}_{17} \mathrm{H}_{24} \mathrm{O}_{4} \mathrm{~S}_{2}(\mathrm{M}+)$ 356.1116; found $=379.1010\left([\mathrm{M}+\mathrm{Na}]^{+}, 100\right)$.

3c: pale-yellow oil, yield: $28.6 \%$. Eluent: PE/EA $=2: 1(v / v) .{ }^{1} \mathrm{H}-\mathrm{NMR}\left(400 \mathrm{MHz}, \mathrm{CDCl}_{3}\right): \delta(\mathrm{ppm})$ 7.50-7.00 (m, 4H, PhH), 5.17 (s, 1H, -SCHS-), 3.79-3.33 (m, 8H, - $\left.\mathrm{CH}_{2} \mathrm{OCH}_{2}-\right)$, 3.19-3.10 (m, 2H, ring $\mathrm{CH}), 2.90-2.76\left(\mathrm{~m}, 4 \mathrm{H},-\mathrm{SCH}_{2}\right), 2.74-2.61\left(\mathrm{~m}, 4 \mathrm{H}\right.$, ring $\left.\mathrm{CH}_{2}\right) .{ }^{13} \mathrm{C}-\mathrm{NMR}\left(100 \mathrm{MHz}, \mathrm{CDCl}_{3}\right): \delta(\mathrm{ppm})$ 163.39, 160.94, 136.16, 136.13, 129.52, 129.44, 115.50, 115.29, 71.56, 71.02, 53.08, 50.74, 50.73,44.09, 31.82, 30.90. HRMS (ESI): $m / z$ calcd. for $\mathrm{C}_{17} \mathrm{H}_{23} \mathrm{FO}_{4} \mathrm{~S}_{2}(\mathrm{M}+)$ 374.1022; found $=397.0919\left([\mathrm{M}+\mathrm{Na}]^{+}, 100\right)$.

3d: pale-yellow oil, yield: 21.3\%. Eluent: PE/EA $=2: 1(v / v) .{ }^{1} \mathrm{H}-\mathrm{NMR}\left(400 \mathrm{MHz}, \mathrm{CDCl}_{3}\right): \delta(\mathrm{ppm})$ 7.62-7.57 (m, 4H, $\mathrm{PhH}), 5.24$ (s, $1 \mathrm{H},-\mathrm{SCHS}-), 3.82-3.29\left(\mathrm{~m}, 8 \mathrm{H},-\mathrm{CH}_{2} \mathrm{OCH}_{2}-\right), 3.17-3.10(\mathrm{~m}, 2 \mathrm{H}$, ring $\mathrm{CH}), 2.89-2.77\left(\mathrm{~m}, 4 \mathrm{H},-\mathrm{SCH}_{2}\right), 2.74-2.57\left(\mathrm{~m}, 4 \mathrm{H}\right.$, ring $\left.\mathrm{CH}_{2}\right) .{ }^{13} \mathrm{C}-\mathrm{NMR}\left(100 \mathrm{MHz}, \mathrm{CDCl}_{3}\right): \delta(\mathrm{ppm})$ 144.52, 128.31, 128.20, 125.57, 125.53, 73.41, 72.45, 72.44, 72.20, 71.62, 71.08, 71.06, 69.51, 53.30, 50.77, 50.76, 45.78, 44.09, 31.88, 30.86. HRMS (ESI): $\mathrm{m} / z$ calcd. for $\mathrm{C}_{18} \mathrm{H}_{23} \mathrm{~F}_{3} \mathrm{O}_{4} \mathrm{~S}_{2}(\mathrm{M}+)$ 424.0990; found $=$ $447.0890\left([\mathrm{M}+\mathrm{Na}]^{+}, 100\right)$.

\subsubsection{Synthesis and Characterization of Target Polymers 4}

In a typical polymerization procedure, PEI $600 \mathrm{Da}(0.5 \mathrm{mmol})$ and diglycidyl ether linkers 3 $(0.5 \mathrm{mmol})$ were dissolved with $1 \mathrm{~mL}$ of anhydrous $\mathrm{EtOH}$ in a container. Under the protection of nitrogen $\left(\mathrm{N}_{2}\right)$, the reaction mixture was stirred at $80{ }^{\circ} \mathrm{C}$ for $72 \mathrm{~h}$. The resulting crude product was recrystallized from anhydrous DCM/methanol $(v / v=1 / 1)$. The recrystallized oily precipitate was isolated and dried until a constant weight was achieved. The molecular weights of compounds 4 were measured by GPC.

4a: Yield: 35.6\%. ${ }^{1} \mathrm{H}-\mathrm{NMR}\left(400 \mathrm{MHz}, \mathrm{D}_{2} \mathrm{O}\right): \delta(\mathrm{ppm}) 7.55-6.80(\mathrm{~m}, 4 \mathrm{H}, \mathrm{PhH}), 5.18$ (s, 1H, -SCHS-), 3.98-2.20 (m, 33H, - $\mathrm{SCH}_{2} \mathrm{CH}_{2} \mathrm{O}-,-\mathrm{OCH}_{2} \mathrm{CH}(\mathrm{OH}) \mathrm{CH}_{2^{-}},-\mathrm{NHCH}_{2} \mathrm{CH}_{2}-$ ). GPC: $\mathrm{M}_{\mathrm{w}}=9871, \mathrm{PDI}=1.85$.

4b: Yield: 37.1\%. ${ }^{1} \mathrm{H}-\mathrm{NMR}\left(400 \mathrm{MHz}, \mathrm{D}_{2} \mathrm{O}\right): \delta(\mathrm{ppm}) 7.63-7.00(\mathrm{~m}, 5 \mathrm{H}, \mathrm{PhH}), 5.17(\mathrm{~s}, 1 \mathrm{H},-\mathrm{SCHS}-)$, 4.08-1.94 (m, 42H, -SCH $\mathrm{CH}_{2} \mathrm{O}-,-\mathrm{OCH}_{2} \mathrm{CH}(\mathrm{OH}) \mathrm{CH}_{2-}^{-},-\mathrm{NHCH}_{2} \mathrm{CH}_{2}-$ ). GPC: $\mathrm{M}_{\mathrm{w}}=10,916, \mathrm{PDI}=1.97$.

4b: Yield: 29.8\%. ${ }^{1} \mathrm{H}-\mathrm{NMR}\left(400 \mathrm{MHz}, \mathrm{D}_{2} \mathrm{O}\right): \delta$ (ppm) 7.45-6.64 (m, 4H, PhH), 5.13 (s, 1H, -SCHS-), 4.11-2.01 (m, 35H, - $\left.\mathrm{SCH}_{2} \mathrm{CH}_{2} \mathrm{O}-,-\mathrm{OCH}_{2} \mathrm{CH}(\mathrm{OH}) \mathrm{CH}_{2-}^{-},-\mathrm{NHCH}_{2} \mathrm{CH}_{2}-\right)$. GPC: $\mathrm{M}_{\mathrm{w}}=7123, \mathrm{PDI}=1.70$.

4b: Yield: 31.2\%. ${ }^{1} \mathrm{H}-\mathrm{NMR}\left(400 \mathrm{MHz}, \mathrm{D}_{2} \mathrm{O}\right): \delta(\mathrm{ppm})$ 7.77-7.18 (m, 4H, $\left.\mathrm{PhH}\right), 5.21$ (s, 1H, -SCHS-), 4.02-2.05 (m, 38H, $\left.-\mathrm{SCH}_{2} \mathrm{CH}_{2} \mathrm{O}-,-\mathrm{OCH}_{2} \mathrm{CH}(\mathrm{OH}) \mathrm{CH}_{2-}^{-},-\mathrm{NHCH}_{2} \mathrm{CH}_{2}-\right)$. GPC: $\mathrm{M}_{\mathrm{w}}=8209 \mathrm{PDI}=1.40$.

\subsection{Reactive Oxygen Species-Triggered Degradation of Thioketal Linkages}

The degradation of thioketal linkages in polymer 4 under ROS conditions was investigated by incubating $4(5 \mathrm{mg})$ with $100 \mathrm{mM}$ of $\mathrm{H}_{2} \mathrm{O}_{2}$ in $0.6 \mathrm{~mL}$ of $\mathrm{D}_{2} \mathrm{O}$ at $37^{\circ} \mathrm{C}$ for various periods of time. The disappearance of the thioketal linkage peak $(\delta \sim 5.20 \mathrm{ppm})$ was analyzed by using ${ }^{1} \mathrm{H}-\mathrm{NMR}$.

\subsection{Agarose Gel Retardation}

pUC-19 ( $5 \mu \mathrm{L}$ of $0.025 \mathrm{mg} / \mathrm{mL}$ in $\mathrm{H}_{2} \mathrm{O}$ ) was mixed with the required amount of polymer to obtain the varied $w / w$ ratios in $\mathrm{H}_{2} \mathrm{O}$ (a total volume of $10 \mu \mathrm{L}$ ). After an incubation time of $30 \mathrm{~min}$ at $37^{\circ} \mathrm{C}$, the polyplex solution was loaded onto an agarose gel $\left(0.7 \% w / v\right.$ agarose gel containing GelRed $\left.{ }^{\mathrm{TM}}\right)$ and electrophoresed at $120 \mathrm{~V}$ for $40 \mathrm{~min}$. A Vilber Lourmat imaging system was utilized to image the agarose gels [36].

To investigate the polymer stability under ROS conditions, the polymer solution $(1 \mathrm{mg} / \mathrm{mL})$ was treated with $100 \mathrm{mM} \mathrm{H}_{2} \mathrm{O}_{2}$ for $48 \mathrm{~h}$ at $37^{\circ} \mathrm{C}$. Subsequently, $0.125 \mu \mathrm{g}$ pUC-19 and the desired amount 
of polymers at vary $w / w$ ratios were mixed in $10 \mu \mathrm{L}$ of DI for $0.5 \mathrm{~h}$. The samples were run at the same electrophoresis condition as described above.

\subsection{Particle Size and Zeta Potential Measurements}

A Malvern Instruments Zetasizer Nano-ZS (ZEN3600, Malvern Instruments Ltd., Worcestershire, UK) was used to measure the complexes size and zeta potential. Polymer/DNA complexes were prepared at varying $w / w$ ratios as described above. Samples were then diluted up to $1 \mathrm{~mL}$ using purity water before being measured [36]. In the experiments with serum, FBS (10\% final concentrations) was added to the formulated polyplexes and mixed for $30 \mathrm{~s}$. The particle sizes of the polyplexes were determined using Dynamic light scattering (DLS). Data were shown as mean \pm standard deviation (S.D.) based on three independent measurements.

\subsection{Reactive Oxygen Species-Responsive of Polyplexes}

The ROS-responsive tests were conducted by mixing the complexes (4a/DNA at $w / w$ of 2 ) with $100 \mu \mathrm{M} \mathrm{H}_{2} \mathrm{O}_{2}$ (final concentrations) at $37{ }^{\circ} \mathrm{C}$ for 1 days. After 12 and $24 \mathrm{~h}$, the polyplexes were measured through DLS to obtain particle sizes and size distributions.

\subsection{In Vitro Transfection Experiments}

Gene transfection of a series of complexes was investigated in HeLa cells using two different plasmids encoding for green fluorescence protein (pEGFP-N1) and luciferase (pGL-3). Cells were seeded at a density of $7 \times 10^{4}$ cells per well in 24 -well plates and incubated for $24 \mathrm{~h}$ to achieve $\sim 70-80 \%$ confluency. The culture medium was replaced with FBS free or $10 \%$ FBS containing DMEM medium before transfection. Polymer/DNA $(1 \mu \mathrm{g})$ complexes were added to each well and incubated at $37^{\circ} \mathrm{C}$. Control reagents $25 \mathrm{KDa} \mathrm{PEI}$ (at a $w / w$ ratio of $1.4, \mathrm{~N} / \mathrm{P}=10$ ) $[4,14,17]$ and Lipofectamine 2000 were formulated with DNA based upon their recommended protocols. After $4 \mathrm{~h}$ of incubation, the transfection medium was replaced with fresh complete medium containing 10\% FBS and further incubated for $20 \mathrm{~h}$. The images of GFP expressed cells were taken with an inverted fluorescence microscope (Nikon Eclipse TE 2000E, Nikon, Tokyo, Japan).

For the luciferase expression, cells were washed twice with PBS (pH 7.4) and lysed using $100 \mu \mathrm{L}$ $1 \times$ Lysis reporter buffer. The luciferase activity was quantified using the luciferase assay reagent (Promega). The total protein content of the cell lysate was analyzed by BCA protein assay. The gene TE was expressed as the relative fluorescence intensity per $\mathrm{mg}$ protein (RLU/mg protein). All transfection experiments were performed as replicates of three [17].

\subsection{Cytotoxicity Assay}

The cytotoxicity studies were performed using Cell Counting Kit-8 (CCK-8) assay. HeLa cells were seeded in 96-well plates at a density of 8000 cells per well and allowed to adhere for $24 \mathrm{~h}$. Complexes prepared at varied $w / w$ ratios $(2,4,6$ corresponding to final concentrations were $4,8,12 \mu \mathrm{g} / \mathrm{mL})$ were added to the FBS free growth medium and left to incubated for $4 \mathrm{~h}$. Following incubation, the wells were replaced with fresh complete medium and incubated for a further $24 \mathrm{~h}$. Subsequently, $10 \mu \mathrm{L}$ of CCK-8 was then added to each well and the cells were incubated for $1 \mathrm{~h}$ at $37^{\circ} \mathrm{C}$. After that, the aborbance was readed using enzyme-linked immunosorbent assay (ELISA) plate reader (Model 680, Bio-Rad, Hercules, CA, USA) at a wavelength of $490 \mathrm{~nm}$. The relative cell viability (\%) related to untreated control cells was calculated by test/control $\times 100$ [42]. Values were given as mean of triplicates \pm S.D.

\subsection{Statistical Analysis}

Results are summarized as mean \pm S.D., and statistical significance of differences was evaluated by variance analysis (ANOVA): $p$ values smaller than 0.05 were considered to be significant [39]. 


\section{Conclusions}

In summary, we have successfully synthesized a series of ROS-responsive materials by the ring-opening polymerization between PEI 600 and diepoxide containing stimuli-responsive thioacetal groups. Four diglycidyl ethers with various electron-effects were employed in the side chain structure to facilitate the study of the SAR. These materials could efficiently condense DNA into stable nanoparticles with proper sizes and zeta-potentials. Besides, the thioketal linkages in polymers could also be dissociated under ROS-rich conditions for efficient gene delivery. Compared with $25 \mathrm{KDa}$ PEI and Lipofectamine 2000, these polymers showed much higher TE in HeLa cells, especially polymer 4a with electron-withdrawing substituent on the aromatic ring. More importantly, unlike PEI, serum had little negative effect on the transfection by these materials, and their TEs were even increased with the presence of $10 \%$ serum. The better serum tolerance of the polymers might come from their evenly distributed hydroxyl groups. Moreover, the cationic polymers exhibited good cell viabilities. The collective data suggested such polymer could be a promising target nanocarrier exploiting the high levels of intracellular ROS in cancer cells. Further modifications of the polymer structure and in-depth mechanism studies are now in progress.

Supplementary Materials: The following are available online. Figure S1-S3 and Table S1. Additionally, ${ }^{1} \mathrm{H},{ }^{19} \mathrm{~F}$ and ${ }^{13} \mathrm{C}-\mathrm{NMR}$ and GPC data for the compounds are provided.

Author Contributions: W.-J.Y. and Q.L. conceived and designed the experiments; G.-Q.L. performed the experiments; W.-J.Y. wrote the paper; Z.-G.Z. and X.-J.Y. provide the resources.

Funding: This work was financially supported by the National Science Foundation of China (No. 2170021243), the Science and Technology Department of Sichuan Province (No. 2015JY0115), and the Fundamental Research Funds for the Central Universities, Southwest Minzu University (No. 2018HQZZ19).

Acknowledgments: Wen-Jing Yi thanks Xiao-Qi Yu and Ji Zhang from the Key Laboratory of Green Chemistry and Technology (Ministry of Education), College of Chemistry, Sichuan University for their support.

Conflicts of Interest: The authors declare there is no conflicts of interest regarding the publication of this paper.

\section{References}

1. Cho, H.; Cho, Y.-W.; Kang, S.-W.; Kwak, M.-K.; Huh, K.M.; Bae, Y.H.; Kang, H.C. Tempo-spatial activation of sequential quadruple stimuli for high gene expression of polymeric gene nanocomplexes. Mol. Pharm. 2017, 14, 842-855. [CrossRef] [PubMed]

2. Ilarduya, C.T.D.; Sun, Y.; Düzgüneş, N. Gene delivery by lipoplexes and polyplexes. Eur. J. Pharm. Sci. 2010, 40, 159-170. [CrossRef] [PubMed]

3. Mintzer, M.A.; Simanek, E.E. Nonviral vectors for gene delivery. Chem. Rev. 2009, 109, 259-302. [CrossRef] [PubMed]

4. Xu, C.-T.; Chen, G.; Nie, X.; Wang, L.-H.; Ding, S.-G.; You, Y.-Z. Low generation PAMAM-based nanomicelles as ROS-responsive gene vectors with enhanced transfection efficacy and reduced cytotoxicity in vitro. New J. Chem. 2017, 41, 3273-3279. [CrossRef]

5. Bouard, D.; Alazard-Dany, N.; Cosset, F.L. Viral vectors: From virology to transgene expression. Br. J. Pharmacol. 2009, 157, 153-165. [CrossRef] [PubMed]

6. Guan, Y.; Lu, H.; Li, W.; Zheng, Y.; Jiang, Z.; Zou, J.; Gao, H. Near-infrared triggered upconversion polymeric nanoparticles based on aggregation-induced emission and mitochondria targeting for photodynamic cancer therapy. ACS Appl. Mater. Interfaces 2017, 9, 26731-26739. [CrossRef] [PubMed]

7. Chen, W.; Deng, W.; Goldys, E.M. Light-triggerable liposomes for enhanced endolysosomal escape and gene silencing in PC12 cells. Mol. Ther. Nucleic Acids 2017, 7, 366-377. [CrossRef] [PubMed]

8. Lee, D.-J.; He, D.; Kessel, E.; Padari, K.; Kempter, S.; Lächelt, U.; Rädler, J.O.; Pooga, M.; Wagner, E. Tumoral gene silencing by receptor-targeted combinatorial siRNA polyplexes. J. Control. Release 2016, 244 Pt B, 280-291. [CrossRef]

9. Truong, N.P.; Gu, W.; Prasadam, I.; Jia, Z.; Crawford, R.; Xiao, Y.; Monteiro, M.J. An influenza virus-inspired polymer system for the timed release of siRNA. Nat. Commun. 2013, 4, 1902. [CrossRef] [PubMed] 
10. Hartono, S.B.; Phuoc, N.T.; Yu, M.; Jia, Z.; Monteiro, M.J.; Qiao, S.; Yu, C. Functionalized large pore mesoporous silica nanoparticles for gene delivery featuring controlled release and co-delivery. J. Mater. Chem. B 2014, 2, 718-726. [CrossRef]

11. Rosariomeléndez, R.; Yu, W.; Uhrich, K.E. Biodegradable polyesters containing ibuprofen and naproxen as pendant groups. Biomacromolecules 2013, 14, 3542-3548. [CrossRef] [PubMed]

12. Neu, M.; Fischer, D.; Kissel, T.J. Recent advances in rational gene transfer vector design based on poly(ethylene imine) and its derivatives. J. Gene Med. 2005, 7, 992-1009. [CrossRef] [PubMed]

13. Xun, M.-M.; Zhang, J.-H.; Liu, Y.-H.; Zhang, J.; Xiao, Y.-P.; Guo, Q.; Li, S.; Yu, X.-Q. Polyethylenimine analogs for improved gene delivery: Effect of the type of amino groups. RSC Adv. 2016, 6, 5391-5400. [CrossRef]

14. Li, H.; Jiang, H.; Zhao, M.; Fu, Y.; Sun, X. Intracellular redox potential-responsive micelles based on polyethylenimine-cystamine-poly( $\varepsilon$-caprolactone) block copolymer for enhanced miR-34a delivery. Polym. Chem. 2015, 6, 1952-1960. [CrossRef]

15. Sarkar, K.; Debnath, M.; Kundu, P.P. Preparation of low toxic fluorescent chitosan-graft-polyethyleneimine copolymer for gene carrier. Carbohydr. Polym. 2013, 92, 2048-2057. [CrossRef] [PubMed]

16. Yoshitomi, T.; Hirayama, A.; Nagasaki, Y. The ROS scavenging and renal protective effects of pH-responsive nitroxide radical-containing nanoparticles. Biomaterials 2011, 32, 8021-8028. [CrossRef] [PubMed]

17. Xun, M.-M.; Xiao, Y.-P.; Zhang, J.; Liu, Y.-H.; Peng, Q.; Guo, Q.; Wu, W.-X.; Xu, Y.; Yu, X.-Q. Low molecular weight PEI-based polycationic gene vectors via Michael addition polymerization with improved serum-tolerance. Polymer 2015, 65, 45-54. [CrossRef]

18. Mao, C.Q.; Du, J.Z.; Sun, T.M.; Yao, Y.D.; Zhang, P.Z.; Song, E.W.; Wang, J. A biodegradable amphiphilic and cationic triblock copolymer for the delivery of siRNA targeting the acid ceramidase gene for cancer therapy. Biomaterials 2011, 32, 3124-3133. [CrossRef] [PubMed]

19. Liu, S.; Huang, W.; Jin, M.-J.; Fan, B.; Xia, G.-M.; Gao, Z.-G. Inhibition of murine breast cancer growth and metastasis by survivin-targeted siRNA using disulfide cross-linked linear PEI. Eur. J. Pharm. Sci. 2016, 82, 171-182. [CrossRef] [PubMed]

20. Yuan, Y.; Zhang, C.J.; Liu, B. A photoactivatable AIE polymer for light-controlled gene delivery: Concurrent endo/lysosomal escape and DNA unpacking. Angew. Chem. Int. Ed. 2015, 54, 1-6. [CrossRef] [PubMed]

21. Kim, J.; Lee, Y.M.; Kim, H.; Park, D.; Kim, J.; Kim, W.J. Phenylboronic acid-sugar grafted polymer architecture as a dual stimuli-responsive gene carrier for targeted anti-angiogenic tumor therapy. Biomaterials 2016, 75, 102-111. [CrossRef] [PubMed]

22. Ganta, S.; Devalapally, H.; Shahiwala, A.; Amiji, M. A review of stimuli-responsive nanocarriers for drug and gene delivery. J. Control. Release 2008, 126, 187-204. [CrossRef] [PubMed]

23. Fleige, E.; Quadir, M.A.; Haag, R. Stimuli-responsive polymeric nanocarriers for the controlled transport of active compounds: Concepts and applications. Adv. Drug Deliv. Rev. 2012, 64, 866-884. [CrossRef] [PubMed]

24. Li, Y.; Gao, J.; Zhang, C.; Cao, Z.; Cheng, D.; Liu, J.; Shuai, X. Stimuli-responsive polymeric nanocarriers for efficient gene delivery. Top. Curr. Chem. 2017, 375, 27. [CrossRef] [PubMed]

25. Liu, X.; Wang, Y.; Chen, C.; Tintaru, A.; Cao, Y.; Liu, J.; Ziarelli, F.; Tang, J.; Guo, H.; Rosas, R.; et al. A fluorinated bola-amphiphilic dendrimer for on-demand delivery of siRNA, via specific response to reactive oxygen species. Adv. Funct. Mater. 2016, 26, 8594-8603. [CrossRef]

26. Shim, M.S.; Xia, Y. A reactive oxygen species (ROS)-responsive polymer for safe, efficient, and targeted gene delivery in cancer cells. Angew. Chem. Int. Ed. 2013, 52, 6926-6929. [CrossRef] [PubMed]

27. He, X.; Chen, X.; Liu, L.; Zhang, Y.; Lu, Y.; Zhang, Y.; Chen, Q.; Ruan, C.; Guo, Q.; Li, C.; et al. Sequentially triggered nanoparticles with tumor penetration and intelligent drug release for pancreatic cancer therapy. Adv. Sci. 2018, 5, 1701070. [CrossRef] [PubMed]

28. Yoo, J.; Rejinold, N.S.; Lee, D.; Jon, S.; Kim, Y.C. Protease-activatable cell-penetrating peptide possessing ROS-triggered phase transition for enhanced cancer therapy. J. Control. Release 2017, 264, 89-101. [CrossRef] [PubMed]

29. Zhang, Q.; Zhang, F.; Chen, Y.; Dou, Y.; Tao, H.; Zhang, D.; Wang, R.; Li, X.; Zhang, J. Structure-property correlations of reactive oxygen species-responsive and hydrogen peroxide-eliminating materials with anti-oxidant and anti-inflammatory activities. Chem. Mater. 2017, 29, 8221-8238. [CrossRef]

30. Lee, S.H.; Boire, T.C.; Lee, J.B.; Gupta, M.K.; Zachman, A.L.; Rath, R.; Sung, H.J. ROS-cleavable proline oligomer crosslinking of polycaprolactone for pro-angiogenic host response. J. Mater. Chem. B 2014, 2, 7109-7113. [CrossRef] [PubMed] 
31. Yu, L.-Y.; Su, G.-M.; Chen, C.-K.; Chiang, Y.-T.; Lo, C.-L. Specific cancer cytosolic drug delivery triggered by oxygen species-responsive micelles. Biomacromolecules 2016, 17, 3040-3047. [CrossRef] [PubMed]

32. Wilson, D.S.; Dalmasso, G.; Wang, L.; Sitaraman, S.V.; Merlin, D.; Murthy, N. Orally delivered thioketal nanoparticles loaded with TNF- $\alpha$-siRNA target inflammation and inhibit gene expression in the intestines. Nat. Mater. 2010, 9, 923-928. [CrossRef] [PubMed]

33. Song, C.-C.; Du, F.-S.; Li, Z.-C. Oxidation-responsive polymers for biomedical applications. J. Mater. Chem. B 2014, 2, 3413-3426. [CrossRef]

34. Cheng, R.; Meng, F.; Deng, C.; Zhong, Z. Bioresponsive polymeric nanotherapeutics for targeted cancer chemotherapy. Nano Today 2015, 10, 656-670. [CrossRef]

35. Saravanakumar, G.; Kim, J.; Kim, W.J. Reactive-oxygen-species-responsive drug delivery systems: Promises and challenges. Adv. Sci. 2017, 4, 1600124. [CrossRef] [PubMed]

36. Luo, C.Q.; Xing, L.; Cui, P.F.; Qiao, J.B.; He, Y.J.; Chen, B.A.; Jin, L.; Jiang, H.L. Curcumin-coordinated nanoparticles with improved stability for reactive oxygen species-responsive drug delivery in lung cancer therapy. Int. J. Nanomed. 2017, 12, 855-869. [CrossRef] [PubMed]

37. Yi, W.-J.; Yu, X.-C.; Wang, B.; Zhang, J.; Yu, Q.-Y.; Zhou, X.-D.; Yu, X.-Q. TACN-based oligomers with aromatic backbones for efficient nucleic acid delivery. Chem. Commun. 2014, 50, 6454-6457. [CrossRef] [PubMed]

38. Luan, C.-R.; Liu, Y.-H.; Zhang, J.; Yu, Q.-Y.; Huang, Z.; Wang, B.; Yu, X.-Q. Low molecular weight oligomers with aromatic backbone as efficient nonviral gene vectors. ACS Appl. Mater. Interfaces 2016, 8, 10743-10751. [CrossRef] [PubMed]

39. Liu, Q.; Su, R.-C.; Yi, W.-J.; Zhao, Z.-G. Biodegradable poly(amino ester) with aromatic backbone as efficient nonviral gene delivery vectors. Molecules 2017, 22, 566. [CrossRef] [PubMed]

40. Yi, W.-J.; Zhang, Q.-F.; Zhang, J.; Liu, Q.; Ren, L.; Chen, Q.-M.; Guo, L.; Yu, X.-Q. Cyclen-based lepidic oligomers as potential gene delivery vehicles. Acta Biomater. 2014, 10, 1412-1422. [CrossRef] [PubMed]

41. Zhang, Q.-F.; Yu, Q.-Y.; Geng, Y.; Zhang, J.; Wu, W.-X.; Wang, G.; Gu, Z.; Yu, X.-Q. Ring-opening polymerization for hyperbranched polycationic gene delivery vectors with excellent serum tolerance. ACS Appl. Mater. Interfaces 2014, 6, 15733-15742. [CrossRef] [PubMed]

42. Guo, Q.; Liu, Y.-H.; Xun, M.-M.; Zhang, J.; Huang, Z.; Zhou, X.-D.; Yu, X.-Q. Diol glycidyl ether-bridged low molecular weight PEI as potential gene delivery vehicles. J. Mater. Chem. B 2015, 3, 2660-2670. [CrossRef]

43. Yudovin-Farber, I.; Domb, A.J. Cationic Polysaccharides for Gene Delivery. Mater. Sci. Eng. C 2007, 27, 595-598. [CrossRef]

44. Liu, Y.M.; Reineke, T.M. Hydroxyl stereochemistry and amine number within Poly(glycoamidoamine)s affect intracellular DNA delivery. J. Am. Chem. Soc. 2005, 127, 3004-3015. [CrossRef] [PubMed]

45. He, Y.; Cheng, G.; Xie, L.; Nie, Y.; He, B.; Gu, Z. Polyethyleneimine/DNA polyplexes with reduction-sensitive hyaluronic acid derivatives shielding for targeted gene delivery. Biomaterials 2013, 34, 1235-1245. [CrossRef] [PubMed]

46. Laskar, R.A.; Begum, N.A.; Mir, M.H.; Rohman, M.R.; Khan, A.T. Nickel(II) chloride hexahydrate catalyzed reaction of aromatic aldehydes with 2-mercaptoethanol: Formation of supramolecular helical assemblage of the product. Tetrahedron Lett. 2013, 54, 5839-5844. [CrossRef]

Sample Availability: Not available.

(C) 2018 by the authors. Licensee MDPI, Basel, Switzerland. This article is an open access article distributed under the terms and conditions of the Creative Commons Attribution (CC BY) license (http:// creativecommons.org/licenses/by/4.0/). 